\title{
WFUMB 2021 Timișoara, Romania
}

During 26-29 May 2021 Timișoara will be The World Capital of Ultrasound, with three major ultrasound events in conjunction: The $18^{\text {th }}$ World Federation for Medicine and Biology Congress - WFUMB 2021, the $33^{\text {rd }}$ Congress of EFSUMB - EUROSON 2021 and the $24^{\text {th }}$ National Conference of The Romanian Society of Ultrasound in Medicine and Biology.
It is also an opportunity to visit our beautiful town, Timișoara - "The Little Vienna" or "The City of Flowers", and to discover the Romanian hospitality.

WFUMB 2021 will maintain the tradition of a balanced program, including a range of postgraduate courses focused on different fields of ultrasound and will also bring the newest information in diagnostic and interventional ultrasonography, covering the usual broad range of topics and encouraging the original research in ultrasound. With more than 100 invited speakers the program will suit everyone.

Join us for a wonderful WFUMB Congress in 2021 in Timișoara!

Prof. Ioan Sporea, MD, PhD

Congress President 